\title{
Reactive arthritis developing after pneumococcal conjunctivitis: a
} case report

\author{
Amit S Verma*1 and Dorian Dwarika²
}

\author{
Address: ${ }^{1}$ Western General Hospital, Crewe Road, Edinburgh, UK and ${ }^{2}$ City Hospital, Dudley Road, Birmingham, UK \\ Email: Amit S Verma* - sedna1973@yahoo.co.uk; Dorian Dwarika - Dwarika5@aol.com \\ * Corresponding author
}

Published: 2 February 2007

Received: 26 December 2006

Journal of Medical Case Reports 2007, 1:2 doi:10.1 186/1752-1947-I-2

Accepted: 2 February 2007

This article is available from: http://www.jmedicalcasereports.com/content/I/I/2

(c) 2007 Verma and Dwarika; licensee BioMed Central Ltd.

This is an Open Access article distributed under the terms of the Creative Commons Attribution License (http://creativecommons.org/licenses/by/2.0), which permits unrestricted use, distribution, and reproduction in any medium, provided the original work is properly cited.

\begin{abstract}
Background: S. pneumoniae is a known cause of bacterial conjunctivitis and can be transmitted through contact with infected carriers.

Case presentation: A 38-year-old ophthalmologist developing reactive arthritis following clinicacquired pneumococcal conjunctivitis.

Conclusion: (I) Despite the frequency and largely self-limiting nature of infective conjunctivitis, it should be appropriately assessed and managed, as the natural history can occasionally be associated with significant morbidity. (2) Hygienic measures are required to be implemented by both patients and ophthalmic staff to reduce the likelihood of transmission.
\end{abstract}

\section{Background}

Streptococcus pneumoniae is a known cause of bacterial conjunctivitis. Outbreaks associated with this pathogen have been reported in the medical literature within the past few years [1-3]. Spread through contact with infected carriers has been implicated, as has contact lens wear [1].

We describe the case of an ophthalmologist developing the previously unreported complication of seronegative reactive arthritis after clinic-acquired bacterial conjunctivitis. This case highlights both the potential hazards faced by staff within the clinic setting and the possible morbidity associated with this condition.

\section{Case presentation}

A 38 year-old male ophthalmologist was seen at the Ophthalmic Accident and Emergency Department with a fivehour history of a right watery red eye. He had been exposed to several conjunctivitis patients during the preceding few days, whilst working at the same department.
An initial diagnosis of probable viral conjunctivitis was made, and the patient was prescribed chloramphenicol eye drops. Conjunctival swabs were taken and sent to the microbiology laboratory for analysis. A day later the conjunctivitis had become bilateral and purulent. Several hours after the conjunctivitis became bilateral the patient also developed a sore throat. The previous swab cultures isolated Streptococcus pneumoniae as the infective pathogen. Three days later, the patient noticed tenderness and swelling of the proximal interphalangeal joint of the index finger in the left hand, which became progressively more swollen and tender over the next couple of days. The patient had become febrile; however, there were neither chills nor rigors. He was prescribed oral amoxicillin 500 mg TID and flucloxacillin $500 \mathrm{mg}$ QID, in the belief this was septic arthritis.

Two days after the swelling started he was seen by a rheumatologist, who made a diagnosis of reactive arthritis. The patient was fully investigated (see following text and 
Table I: Selected blood test results. Values both at the time of initial investigation and after two months following the start of treatment with anti-inflammatory drugs.

\begin{tabular}{llll}
\hline Test & Blood test result at time of diagnosis & Blood test result after 2 months & Reference range (and units) \\
\hline White Cell Count & 4.7 & 4.4 & $3.7-9.5\left(\times 10^{9} /\right.$ litre $)$ \\
Neutrophils & 2.01 & 1.65 & $1.7-6.1\left(\times 10^{9} /\right.$ litre $)$ \\
Lymphocytes & 2.07 & 2.25 & $1-3.2\left(\times 10^{9} /\right.$ litre $)$ \\
Monocytes & 0.25 & 0.21 & $0.2-0.6\left(\times 10^{9} /\right.$ litre $)$ \\
Eosinophils & 0.25 & 0.15 & $0.03-0.46\left(\times 10^{9} / \mathrm{litre}\right)$ \\
Basophils & 0.02 & 0.03 & $0.02-0.09\left(\times 10^{9} / \mathrm{litre}\right)$ \\
Platelets & 308 & 269 & $143-400\left(\times 10^{9} / \mathrm{litre}\right)$ \\
CRP & $<5$ & $<5$ & $0-5(\mathrm{mg} / \mathrm{litre})$ \\
ESR & 17 & 8 & $1-10(\mathrm{~mm} / \mathrm{hour})$ \\
\hline
\end{tabular}

Table 1). Plain X-ray showed a little soft tissue swelling over the proximal interphalangeal joint of the left index finger. The patient was negative for antineutrophil cytoplasmic antibodies (ANCA), rheumatoid factor (RF), antiDNA antibodies and antinuclear antibodies; complement factors $\mathrm{C} 3$ and $\mathrm{C} 4$ were within the reference range. No pathogen could be grown in blood culture and joint aspiration (performed by the rheumatologist) yielded no synovial fluid. The patient was HLA-B27 negative. A firm diagnosis of reactive arthritis as a sequel to pneumococcal conjunctivitis was made. Anti-inflammatory drugs resolved the swelling and pain within 48 hours. The conjunctivitis had already recovered though the antibiotics were continued until the course was completed.

\section{Discussion and conclusion}

Reactive arthritis was initially used to describe the development of sterile inflammatory arthritis as a sequel to remote infection. Although no specific criteria exist for the diagnosis of reactive arthritis, it is often based clinically on the development of acute oligoarticular arthritis within 24 weeks of a preceding infection. [4]. Over the past two decades, a clinical entity termed 'post-streptococcal reactive arthritis' (PSRA) has been used to describe a cluster of symptoms sharing features with both acute rheumatic fever and HLA-B27-related spondyloarthropathies. Although sore throat is the common feature and the most frequent site for positive cultures is the throat, streptococcal isolates have been also been obtained from blood cultures and high vaginal/endocervical swabs [5]. Whilst conjunctivitis has been reported as an associated feature in three PSRA cases $[6,7]$, we believe this is the first report of reactive arthritis developing as a consequence of primary pneumococcal conjunctivitis.

Reactive arthritis has usually been described in the context of preceding urogenital or enteric infections. However, in common with both urogenital and enteric infections, streptococci can invade mucosal surfaces. Cell surface components and extracellular products facilitate streptococcal tissue invasion [8]. The precise mechanism(s) by which reactive arthritis could develop remain uncertain [9].

Hygienic measures such as frequent hand washing, disinfection of ophthalmic equipment particularly after infected cases, and the use of disposable tonometer prisms are designed to reduce the risk of infection transmission in the clinic setting. Studies have shown that hand hygiene is not always practised by a substantial proportion of ophthalmic healthcare workers [10] and that ophthalmologists can carry a significant microbial load on their hands [11]. This case shows the risk faced by healthcare workers whilst treating infected patients and highlights the importance of the implementation of hygienic measures by both patients (through education on the importance of frequent hand washing and avoiding the sharing of eating utensils/towels) and healthcare workers to reduce the risk of transmission. It also emphasizes that regardless of the frequency of presentation; rare serious consequences of infective conjunctivitis can and do occur and need to be recognised and managed appropriately, using a multi-disciplinary approach if required.

\section{Competing interests}

The author(s) declare that they have no competing interests.

\section{Authors' contributions}

All authors were involved in writing/reviewing the manuscript. All authors approved the final manuscript.

\section{Acknowledgements}

Full written consent has been obtained from the patient for submission of this manuscript for publication. Funding was neither sought nor obtained.

\section{References}

I. Martin M, Turco JH, Zegans ME, Facklam RR, Sodha S, Elliot JA, Pryor $J$, Beall B, Erdman DD, Baumgartner YY, Sanchez PA, Schwatrzman JD, Montero J, Schuchat A, Whitney CG: An Outbreak of Conjunctivitis Due to Atypical Streptococcus pneumoniae. $\mathrm{N}$ Engl ] Med 2003, 348: I I 2-1 | 21 .

2. Centers for Disease Control and Prevention: Outbreak of Bacterial Conjunctivitis at a College-New Hampshire, JanuaryMarch, 2002. Morb Mortal Wkly Rep 2002, 5 I:205-207. 
3. Centers for Disease Control and Prevention: Pneumococcal Conjunctivitis at an Elementary School - Maine, September 20December 6, 2002. Morb Mortal Wkly Rep 2003, 52:64-66.

4. Hannu T, Inman R, Granfors K, Leirisalo-Repo L: Reactive arthritis or post-infectious arthritis? Best Pract Res Clin Rheumatol 2006, 20:419-33.

5. Mackie SL, Keat A: Poststreptococcal reactive arthritis: what is it and how do we know? Rheumatology 2004, 43:949-954.

6. Rogerson SJ, Beeching NJ: Reactive arthritis complicating group G streptococcal septicaemia. J Infect 1990, 20:155-I58.

7. Madhuri V, Mathai E, Brahmadathan KN, Korula RJ, John TJ: An outbreak of post-streptococcal reactive arthritis. Indian J Med Res 1997, 105:249-253.

8. Kadioglu A, Andrew PW: The innate immune response to pneumococcal lung infection: the untold story. Trends Immunol 2004, 25:143-149.

9. Kim T-H, Uhm W-S, Inman RD: Pathogenesis of ankylosing spondylitis and reactive arthritis. Curr Opin Rheumatol 2005, 17:400-405.

10. Mensah E, Murdoch IE, Binstead K, Rotheram C, Franks W: Hand hygiene in routine glaucoma clinics. $\mathrm{Br} J$ Ophthalmol 2005, 89: $154 \mid-1542$.

11. Lam RF, Hui M, Leung DYL, Chow VCY, Lam BNM, Leung GM, Lam DSC: Extent and Predictors of Microbial Hand Contamination in a Tertiary Care Ophthalmic Outpatient Practice. Invest Ophthalmol Vis Sci 2005, 46:3578-3583.

Publish with Bio Med Central and every scientist can read your work free of charge

"BioMed Central will be the most significant development for disseminating the results of biomedical research in our lifetime. "

Sir Paul Nurse, Cancer Research UK

Your research papers will be:

- available free of charge to the entire biomedical community

- peer reviewed and published immediately upon acceptance

- cited in PubMed and archived on PubMed Central

- yours - you keep the copyright

Submit your manuscript here:

http://www.biomedcentral.com/info/publishing_adv.asp 